\title{
From Horses To Log Cabins - A \$9 Million Embezzlement Case: How Did The Owner Not Know?
}

Lynn Ruggieri, Roger Williams University, USA

\begin{abstract}
The recent economic recession has forced companies to tighten the reins on expenses and fraud is one expense that companies cannot afford. Fraud, however, is becoming a much larger problem for business. This actual fraud case by an employee at a privately held company details how a $\$ 9$ million embezzlement fraud was committed and detected. This case highlights the identification of the fraud, analysis through the use of the fraud triangle and the weaknesses in the internal control of the organization. This case identifies auditing issues and fraud examination procedures.
\end{abstract}

Keywords: Embezzlement; Internal Controls; Fraud

\section{INTRODUCTION}

\section{Public Company Fraud}

n the mid 1990's a surge of corporate frauds occurred in the U.S. beginning with Enron. Kenneth Lay,
founder of Enron, through the use of accounting loopholes, formed special purpose entities where Lay hid
billions in Enron debt from shareholders.

In 2002, the Securities and Exchange Commission filed civil fraud charges against three former top executives of Tyco, including former CEO L. Dennis Kozlowski, alleging that they failed to disclose multi-million dollar low interest and interest-free loans they took from the company and, in some cases, never repaid. According to the indictment, Kozlowski borrowed $\$ 9$ million to buy property in Florida and $\$ 7$ million to buy a Park Avenue apartment in Manhattan for his wife as part of a divorce settlement. Kozlowski was also charged with awarding himself a $\$ 56$ million bonus and CFO Mark Swartz a $\$ 28$ million bonus, neither of which was disclosed to the board of directors. They also used millions in company money to buy homes, yachts, and jewelry. The accounting firm, PricewaterhouseCoopers, later agreed to pay $\$ 225$ million to settle a lawsuit brought by shareholders of Tyco over a multibillion-dollar accounting fraud. PricewaterhouseCoopers failed to uncover fraud in the accounting scandal and, as a result, Tyco overstated its income by $\$ 5.8$ billion.

The Committee of Sponsoring Organizations (COSO) has conducted studies on the incidence of fraud for companies that were cited by the SEC for financial reporting fraud. "For the 10-year period 1998 to 2007, COSO found the amount and incidences remain high. The total amount of fraud was more the $\$ 120$ billion spread across just 300 companies and the SEC's most commonly cited motivations for fraud included the need to meet internal or external earnings expectations"

\footnotetext{
${ }^{1}$ Rittenberg, L. Johnstone, K. \& Gramling, A. (2012) Auditing A Business Risk Approach. Mason OH; South-Western Cengage Learning (459).
} 


\section{Private Company Fraud}

Fraud is not confined to large companies or top executives. It can be perpetrated by any member of the organization. One study estimated that $85 \%$ of the worst fraud cases were conducted by insiders on the payroll. ${ }^{2}$ According to the Association of Certified Fraud Examiners (ACFE), the median loss caused by occupational frauds was $\$ 159,000$. Nearly one-quarter of the cases caused at least $\$ 1$ million in losses and nine cases caused losses of $\$ 1$ billion or more. Participants estimate U.S. organizations lose 5\% of their annual revenue to fraud which, when applied to the 2006 United States Gross Domestic Product, would translate to approximately $\$ 652$ billion in fraud losses. (ACFE 2006)

Small businesses, however, suffer a disproportionate amount of fraud losses. The median loss suffered by organizations with fewer than 100 employees was $\$ 190,000$ per scheme which was higher than the median loss in even the largest organizations. The most common occupational frauds in small businesses involve employees fraudulently writing company checks, skimming revenues, and processing fraudulent invoices. (ACFE 2006)

Privately held businesses are not subject to the auditing requirements for internal control as are publicly held companies. Therefore, these companies do not monitor internal controls or have effective detective measures in place. Less than $10 \%$ of small businesses had anonymous fraud reporting systems and less than $20 \%$ had internal audit departments, conducted surprise audits, or conducted fraud training for their employees and managers. (ACFE 2006) Most frauds in small business are detected by customer reports or by accident instead of due to proactive detection methods.

The size of the loss caused by occupational fraud is strongly related to the position of the perpetrator. Frauds committed by owners or executives caused a median loss of $\$ 1$ million. This is nearly five times more than the median loss caused by managers and almost 13 times as large as the median loss caused by employees. Most of the occupational fraud schemes involved either the accounting department or upper management. Just over $30 \%$ of the occupational frauds were committed by employees in the accounting department. (ACFE 2006)

\section{Regulations to Detect Fraud}

The fraud discovered at public companies demanded action and both Congress and the accounting profession reacted. Congress enacted the Sarbanes-Oxley Act of 2002, a federal law that set new standards for all US publicly held companies. The Sarbanes-Oxley act requires management to implement internal controls over financial reporting and to certify that the controls have been implemented properly and are operating effectively.

The accounting profession, also in 2002, reacted with the issuance of The Statement on Auditing Standards No. 99: Consideration of Fraud in a Financial Statement Audit (SAS 99). SAS 99 requires an auditor to maintain an attitude of professional skepticism recognizing that the possibility of fraud may exist. "The Center for Audit Quality describes professional skepticism as involving the validation of information through probing questions, the critical assessment of evidence, and attention to inconsistencies." 3

SAS 99 provides for an approach that starts at the planning stage with consideration given to the likelihood that fraud may exist. The planning process is meant to alert auditors to 'red flags' or potential fraud factors to address. These red flags include:

- $\quad$ The auditor should understand the nature of fraud, including the types of fraud, the motivation to commit fraud, and the manner in which it may be perpetrated. This includes being aware of incentives, opportunity and rationalization on the part of the fraudster.

- Inquiries of management and others in the entity

- Evaluation and review of audit evidence

\footnotetext{
${ }^{2}$ Ernst \& Young, Fraud: The Unmanaged Risk; $8^{\text {th }}$ Global Survey, 2002.

${ }^{3}$ Rittenberg, L. Johnstone, K. \& Gramling, A. (2012) Auditing A Business Risk Approach. Mason OH; South-Western Cengage Learning (462). 
This case details a $\$ 9$ million embezzlement at a leading landscape and masonry supplier in Massachusetts, how it happened and how it was detected. The case highlights the need to focus on basic fraud examination procedures. This case can be utilized in a fraud examination or auditing course. Students are exposed to a real fraud situation including the magnitude of the amount, the length of time the fraud continued, the discovery of the fraud, and the eventual judicial conclusion. The students learn to apply the fraud triangle as incorporated in SAS 99 and identify the red flags of fraud.

\section{BACKGROUND}

According to the company website, J \& J Materials Corp, located in Rehoboth, Massachusetts, is a leading landscape and masonry supplier in the Rhode Island and southeastern Massachusetts area. The company supplies items such as concrete paving stones for patios, walkways and outdoor landscaping. The company sells bricks, decorative stone and landscaping supplies. The products are high quality and are meant to be decorative, functional and are eco-friendly. (http://jimaterials.com/) J \& J Materials is one of several related entities. "Additional corporations under the ownership of John Ferreira, the owner of J \& J Materials, include Ferreira Construction Inc., Nantucket Pavers Inc., Blackstone Investments Inc., and JJP Realty Inc. All entities operate in the construction, landscaping and real estate industries."

Angela Buckborough Platt (Platt) was born in 1963, the youngest of three children. Her father worked as a financial analyst for a construction company and her mother suffered from mental illness. Her father's job required frequent moves and by the time she was a teenager, Platt lived in four different east coast states and Great Britain. Her teen years were difficult. Her siblings excelled in school, but she did not. Platt failed in college and later accepted a job as a payroll clerk in upstate New York. In this job, she did well and was promoted to supervisor of accounts receivable and later moved on to a financial management position with a conference management company; but living alone in White Plains, New York, was overwhelming and Platt relocated to Oregon in 1991. She began work in the tourism industry and met widower Kevin Platt. They married in 1992 and had two children. Platt, however, longed for the east coast and the family moved to Cumberland Rhode Island. Platt found work with $\mathbf{J}$ \& J Materials while her husband remained unemployed. (U.S. District Court 2007)

\section{A Trusted Employee}

J \& J Materials hired Platt as a part-time bookkeeper in December 1998 and the owner was so pleased with her performance that he offered her a full time position the next year. John Ferreira, owner of J \& J Materials, grew up on a farm in Massachusetts. He did not attend college but had a knack for business. His construction company had grown tremendously when the economy was booming. On a whim, he started J \& J Materials as small retail operation selling stone to small contractors from a trailer. It grew to several locations and grossed millions. "In 1997 he purchased Nantucket Pavers for $\$ 285,000$ and it grew into a multimillion dollar business selling patio blocks to Home Depot. " ${ }^{\prime 5}$ Ferreira enjoyed his success, owning a helicopter at one point. Over the years, he purchased and sold several businesses and "as a result, he controlled approximately a dozen companies, each with their own financials in an enterprise that grossed \$25 million a year.",

Platt was a trusted employee and soon was overseeing the finances of four companies. However, Platt was having difficulty paying the rent and fearing eviction, she stole her first $\$ 650$ from her employer and no one noticed. From there it escalated. She started small, but by 2002 she had taken nearly $\$ 360,000$. She would come to work dressed as she always had and lived in a modest home. Her only extravagance seemed once a year, when she and her husband would go all out decorating their home for Halloween.

\footnotetext{
${ }^{4}$ U.S District Court of Massachusetts, United States of America v. Angela Buckborough Platt Defendant. Case 1:07-cr-10028.

${ }^{5}$ Swidey, N. (2006, September 17). The Inside Job; The Boss Thought she was the Hardest Working Person on his Payroll, Maybe She was, It's not so Easy Building And Hiding An Extravagant, Second Life with Xompany Money But How Could A Scam This Big Go Unnoticed for So Long? The Boston Globe, 1-4.

${ }^{6} \mathrm{Id}$.
}

(C) 2012 The Clute Institute http://www.cluteinstitute.com/ 


\section{Some Questions}

Platt's husband did not work, staying at home to raise the children. He and Platt had a passion for Halloween and in October their house transformed into everything spooky. "He had animatronic ghouls, a skeleton in the driver's seat of a customized Buick hearse, and a 20 -foot monster called 'The Slayer.' The display inevitably drew the attention of the local papers and TV stations and then so many drive-bys that Platt and her husband had to hire a nightly police detail. Platt's co-workers took notice. Some carpooled to check out the scene, among them Cheryl Santos, Ferreira's sister and credit manager. She liked Platt, but after seeing the overblown Halloween display, she had to ask, "How can you afford all that?" Platt explained that her husband, Kevin, had built some of the attractions, and persuaded people to loan him the rest."

There were other things, however, that did not seem to fit. "Santos remembered that Platt once remarked that she had property in Vermont. Santos knew Platt made just over $\$ 40,000$ a year and her husband did not have a job, but Platt had a ready answer. She said her in-laws had given them a spit of land with a junky trailer. Santos could accept that, but she never understood a much smaller matter. "She bought lunch every single day - and not just a sub or something. She'd get takeout from Applebee's, from Chili's. I mean, jeepers crow, that adds up!" 8

Meanwhile, Platt was feeling pressure from elsewhere at work. The general manager of the Nantucket Pavers plant often found the inventory and profit and-loss reports that Platt gave him didn't make sense. "Nantucket was in the black, but just not by what he thought it should be. "Jesus, I know we're doing well," he said, "and it's not showing." When he would point out errors to Platt, she would respond dismissively, saying she would look into it, but then never get back to him. The manager took his concerns to Ferreira, but the boss was more worried about his companies that weren't making money."9

Ferreira had his different business operations each in its own entity and Platt handled the books and the cash for several entities. When the auditors arrived they sought to obtain the bank statements directly from the banks. "Ferreira thought that was a waste of time. He designated one of his most trustworthy employees as the point person to work with the auditors. "Platt will give you anything you need," he told them. "She's got it all under control." ${ }^{10}$

\section{Spending the Money}

Platt had a passion for horses and purchased several thoroughbreds for her daughter. In 2004 Platt and her husband began construction on a log cabin on 100 acres in rural picturesque Vermont. The cabin had two kitchens with marble floors, four substantial bedrooms, each with its own private bathroom. The basement had a media room and a hand carved pool table. The garage was large enough to house a growing collection of vehicles while the upper level had a video arcade. The Vermont tax assessor valued the estate at an amount in excess of $\$ 1$ million. When construction was complete, the Platts held a party with an extravagant menu including fresh lobster. There were endless refreshments and a full band. When the neighbors inquired about the apparent wealth of their new neighbors, Platt said she was the CEO of several profitable companies. (Marcelo, P 2006)

Later that year the Platts decided they needed yet another home, as the ride to Vermont was over 200 miles from their home in Cumberland, Rhode Island, so they purchased a four bedroom home with an in-house movie theatre in Foster, Rhode Island, just 20 minutes away, for $\$ 500,000$.

Still no one at J\& J Materials realized that anything was wrong. Initially, when Platt began, she would write checks out of one of the company accounts and deposit into her personal account. Later, she would write checks from one company to another company and then to herself. By the end of 2005, she had embezzled $\$ 1$ million in a matter of two months. (Swidey N, 2006)

\footnotetext{
${ }^{7}$ Id.

${ }^{8} \mathrm{Id}$.

${ }^{9}$ Id.

${ }^{10} \mathrm{Id}$.
} 
Meanwhile, at J \& J Materials, Ferreira was consolidating and Platt would be moved from the corporate office, beginning in 2006, to Nantucket Pavers. She would no longer be handling the books for several companies as several companies had been sold. She would focus all her attention on Nantucket Pavers. However, the manager there did not trust Platt and therefore hired a bookkeeper in mid-2006. The new bookkeeper found some of Platt's accounting practices difficult to follow. When invoices did not reconcile to inventory, Platt instructed her to simply override them to make them agree, rather than researching the discrepancy. In subsequent weeks, the bookkeeper noticed checks being written on Wednesdays, when it was usually done only on Fridays. Once when she asked Platt why the last page of a bank statement was missing, Platt told her that the credit manager had a habit of throwing those out. (Swidey N., 2006)

\section{Signs of a Problem}

When the bookkeeper arrived, Platt decreased the number of checks she was writing to herself but soon she began again. She needed the money. Platt had hired a staff of professionals to arrange a spectacular June wedding reception for her brother and his fiancé at her Vermont retreat. "A horticulturist was brought in to build an elaborate English garden for the day, a sound-and-lighting specialist was flown in from California, and an event planner was charged with arranging paid hotel rooms for 200 guests, limos, catering, and live entertainment. Platt had signed contracts promising a 20 -minute performance by Riverdance's 30-member touring troupe (at a cost of $\$ 60,000$, plus an estimated $\$ 200,000$ in expenses) and a one-hour show by singer/composer Burt Bacharach (at a cost of $\$ 95,000$, plus an estimated $\$ 300,000$ in expenses).",11

As Platt was planning the lavish wedding in Vermont, the bookkeeper started asking questions.

The bookkeeper spotted questionable records for several checks, totaling over $\$ 70,000$. The checks were posted to different vendors of Nantucket Pavers, but the amounts were large. The bookkeeper called each vendor to see if the invoice number was correct and asked if the check was received. The vendors each replied that there was no such invoice, purchase or check received. The bookkeeper then contacted the bank and all the checks had been cashed, but they were paid to several of Ferreira's inactive companies.

\section{Discovery}

The vice president retrieved the cancelled checks from the bank. "The vice president called him from the bank saying,"I'm looking at a check here for $\$ 44,000$ made out to Angela Buckborough." "Bring the check back here", Ferreira said. "I'll call the police and call her in." His mind was racing, but he was still hoping this was a onetime thing. Around 4 p.m., Ferreira called Platt into the conference room. There she found the vice president and two Rehoboth police officers. After she waived her Miranda rights, Ferreira slid a copy of the $\$ 44,000$ check across the table to her. "Do you know anything about this?"

She didn't blink. "Yes. I've been stealing money."

"How much?"

"About \$200,000."

"Two hundred thousand dollars! What have you done with it?" 12

Court records indicate that over a 6-year period, Angela Buckborough Platt stole approximately $\$ 6.9$ million from $\mathbf{J} \& \mathbf{J}$ Materials. The stolen money was used for a monumental shopping spree that included a 100 acre ranch in Vermont with a heated saltwater swimming pool, a Colonial style home in Foster, 30 acres of land in Maine, timeshares in Disney World, eight show horses, and five all-terrain vehicles. Also purchased was a fleet of 27 motor vehicles, including a 1964 Ford Thunderbird, a 1928 Ford, a 1923 Model T customized into a novelty car fashioned as a green monster, a 1986 Jaguar, a 1937 Chevy panel car with a mural depicting the movie characters

${ }^{11} \mathrm{Id}$.
${ }^{12} \mathrm{Id}$.

(C) 2012 The Clute Institute http://www.cluteinstitute.com/ 
Bonnie and Clyde, a 1920's beer truck, and a 1927 Ford Roadster, to name a few. Halloween enthusiasts, the Platts purchased Hollywood cinematic props to decorate for Halloween, including a 20-foot smoking dragon and six talking trees, along with a life-size ceramic statute of Al Capone. The Platts also purchased a $\$ 17,000$ diamond stud earring, mounted animals and themed vacation trips. The Platts lavishly furnished all their homes and hosted elaborate parties. They liberally bought gifts for friends, including vacation travel. In Vermont, they regularly would pick up the tab for everyone in the restaurant.

The auditors found the embezzlement to be $\$ 6.7$ million while Platt confessed to $\$ 9$ million. A Rhode Island Superior Court judge ordered Platt, and her husband as an admitted accomplice, to pay Ferreira \$16 million, including penalties, in addition to the $\$ 2$ million worth of personal property that she already turned over to him. Platt pleaded guilty to interstate transportation of stolen property and the US District Court of Massachusetts recommended a period of imprisonment of no less than 55 months.

\section{LEARNING OBJECTIVES}

\section{Apply Cressey's Fraud Triangle}

Donald Cressey was interested in what led persons to become overcome by temptation and, as such, he developed the hypothesis that would be known as the fraud triangle. The first leg of the triangle represents perceived non-shareholder financial need, the second leg represents perceived opportunity, and the third leg stands for rationalization. (Wells, 2011)

Cressey found that non-shareable problems fell into several basic categories, including personal failure, business reversals, status-gaining, and employer-employee relations. Perceived pressure is the motivation for the fraud which can be financial need. Perceived opportunity can be the result of poor internal controls which create the ability. Rationalization allows perpetrators an excuse for what they are doing. (Wells, 2011)

Cressey found that when one has non-shareable financial pressure, it generally can be solved by theft of cash or other assets. A basic and important premise of Cressey's fraud triangle hypothesis is that all three pieces of the triangle must be present in order for fraud to occur. There must fist exist the financial pressure to steal. When the pressure culminates, the employee looks for opportunities to commit fraud to relieve the pressure. The individual who has the need and the opportunity will then rationalize the action.

In this case, Platt had a need as she was the only support for the family and she could not pay the rent. The opportunity presented itself when Ferreira put trust in her. Ferreira gave her control of the bookkeeping and checkwriting functions of several companies. Platt would later rationalize that she considered herself the CEO.

\section{Perceived Pressure}

The non-shareable problems of Platt fall into two categories according to Cressey. First, there is business reversals which include individuals that see their problems as arising from conditions out of their control, such as economic downturns. In this case, the first check Platt wrote was to cover the rent because her husband was unemployed and she feared eviction of her family. The second category to consider is status gaining. Here, individuals are motivated by a desire to improve their status or living beyond their means. Cressey felt that it was not the desire for a better lifestyle that creates the problem; rather, it is the inability to obtain the finer things in life through legitimate means and, at the same time, unwillingness to settle for a lower status that creates the motivation for the trust violation. (Wells, 2011)

In this case, Platt is clearly motivated by the finer things in life as demonstrated by the numerous houses, cars, toys and furnishings, none of which she could have afforded on her own.

The perceived pressure of Platt began as a financial need to pay the rent and then it went on to include maintaining a lifestyle far beyond what her income would support. Her husband enjoyed collecting vehicles and she embezzled enough to purchase 27 for him. Platt had a family to support, which she was doing without the help of 
her husband who was unemployed; there was no extra money for frills. Instead, Platt owned horses and several houses with elaborate furnishings, like heated swimming pools, arcades and theatres. She was also generous beyond what her income would support, picking up the check for strangers in restaurants, bestowing vacations for friends, and throwing her brother a lavish wedding.

\title{
Perceived Opportunity
}

A fraud as extensive as this, involving several companies and as large as this - $\$ 9$ million - required substantial knowledge of the accounting system. Platt was hired as a part-time bookkeeper and within a few months was full time. She worked diligently and quietly, but it appears that the system was not very complicated. Platt had gained the trust of Ferreira and was immediately given a great deal of responsibility. She was allowed to handle the books of several entities without question. She maintained all the bank statements. She also did not appear to have a supervisor to report to. This, along with the lack of internal controls, allowed the fraud to happen.

\section{Rationalization}

Platt did plead guilty to the crime of embezzlement and in the plea agreement she mentioned a difficult childhood and failure in college. It is possible that Platt felt she deserved the lavish lifestyle. Platt also had control over several of the entities; it is possible that she thought of it has her business. When in Vermont, she told neighbors that she was in fact the CEO of several companies. She may also have rationalized that it was alright to take the funds because no one was hurt. The lifestyle of the owner was not diminished and the companies survived the embezzlement.

\section{Identify the 'Red Flags' of SAS 99}

SAS 99 requires the auditor to gather information in order to identify the risks of material misstatement due to fraud. These red flags, when viewed with professional skepticism, may uncover fraudulent activities. If the checks were reviewed in this case, it would have been an immediate red flag as Platt made out the checks to herself personally. Another red flag would have been the amount for, at times, Platt made very large payments to herself. If someone had reviewed the bank statement, the unusually large amounts would have been noted as well as the fact that not all the pages of the bank statement were available. Red flags existed in the fact that Platt was allowed to write all the checks as well; there was no additional signature required. If anyone had examined the dormant corporations, it would be noted that transactions were running through these corporations even though there should have been no activity. The size and volume of activity in these corporations would have been a red flag.

Red flags include lifestyle changes. It was noted that an employee had some suspicions on Platt being able to live on her income of $\$ 40,000$ and be able to order out for lunch every day. The employees also knew of her elaborate Halloween displays that had to be expensive. She also spoke of the home in Vermont. Platt had many unusual items - a fleet of 27 cars and an interest in horses - and was spending time in Vermont. She also had a new home in Foster, Rhode Island, but no one in the organization thought this was cause for concern. Discussions with the owner would be a red flag when he revealed that Platt handled everything.

\section{Identify the weaknesses in Internal Control}

Platt was able to carry on the fraud for the length of time and the dollar amount because of the poor internal controls at J \& J Materials. The internal control framework for most U.S. companies is the Committee of Sponsoring Organizations of the Treadway Commission (COSO) Internal Control-Integrated Framework. (L. Rittenberg, K. Johnstone, \& A. Gramling, 2012) There are five elements of internal control:

\author{
- $\quad$ The Control Environment \\ - $\quad$ Risk Assessment \\ - Control Activities \\ - Information and Communication \\ - $\quad$ Monitoring
}

(C) 2012 The Clute Institute http://www.cluteinstitute.com/ 
The control environment is concerned with the actions, policies, and procedures that reflect the overall attitude of management of an entity about internal control and its importance. Management needs to aim for integrity, ethical values and commitment to competence. Management must lead by example, for through its activities, it provides signals to employees about the importance of internal control. When the model of management is unacceptable behavior, the result will be an ineffective control environment. In this case, Platt had no supervision and the owner had no concerns about viewing the bank statements and had no problem giving Platt full authority of the checkbook. The employees could have reported inconsistencies to management, but there was a tone from management that it was not important. The owner failed in his responsibility as there was no communication from management of behavioral standards by codes of conduct and example. Management, through its activities, should provide clear signals to employees about the importance of internal control. Management failed in its responsibility by allowing Platt to handle all financial matters without requiring supporting documentation. The low or nonexistent level of management scrutiny, along with weak internal control, was an invitation to fraud.

Risk Assessment includes management's identification and analysis of risks relevant to the preparation of the financial statements in accordance with GAAP. Management should design internal controls in order to minimize errors and fraud and to do this management should identify factors that may increase risk, determine the risk of the occurrence of fraud, and take any necessary actions to minimize risk. The owner of $\mathrm{J} \& \mathrm{~J}$ Materials gave no consideration to internal controls or the risk of fraud. He simply trusted Platt and gave her enormous authority over the finances of numerous corporations. There should have been consideration given to the risk of fraud.

Control activities are the policies and procedures that management has established to meet its objectives for financial reporting. Control procedures should include:

- $\quad$ Adequate segregation of duties

- $\quad$ Proper authorization of transactions and activities

- $\quad$ Adequate documents and records

- $\quad$ Physical control over assets and records

- $\quad$ Independent checks on performance

This was clearly a problem in this case. Typical segregation of duties includes separation of the functions of authorization, recordkeeping, and custody. In this case, there was no segregation of duties. Platt had exclusive control of check-writing, accounting and bank statement reconciliation. Platt also had custody of the checkbook allowing her to make transfers to herself and since she also reconciled the statements, management did not realize what she was doing. The reconciliation should have been performed by an independent person who had no authority to write checks, make deposits or execute transfers between accounts.

There was no system of authorization in place. There was no limitation on Platt's authority; she did not need approval to make transfers or payments. Only her signature was needed on checks and for transfers. There was no audit trail available in this case. Platt would remove the pages of the bank statements that would implicate her. The auditors received the bank statements from Platt rather than the bank.

Documentation at this company was lax. Platt was able to pay vendors and herself without any documentation. Adequate documentation includes the use of pre-numbered consecutive documents prepared in conjunction with the transaction. All documentation went through Platt. The manager at Nantucket Pavers did not understand the inventory numbers and was not able to receive any documentation because control of the documents rested with Platt, and finally, there were no independent checks in this company. There should be procedures in place in order to check the performance of employees.

Information and communication are the methods used to initiate, record, process, and report an entity's transactions and to maintain accountability for related assets. A company of this size and with several entities requires a system that includes carefully defined responsibilities and written procedures. There was no system in place for J \& J Materials. The company grew over the years to where it was very profitable, but the accounting controls did not grow with the company. There were no defined lines of responsibility and as long as the business was doing well, employees and cash positions were not reviewed. 


\section{CONCLUSION}

In conclusion, Platt was able to perform multiple functions and her work was not reviewed in any way or by anyone. It was not reviewed by the owner or the auditor. Because there were no controls, Platt was able to embezzle greater and greater amounts and it went undetected.

In order to improve the controls and prevent fraud, the company should have segregated duties. Other preventative measures include dollar limitations on check signing authority or requiring a second signature for check amounts over a certain dollar amount. The company also should have had measures in place requiring approval for bank transfers. These controls are basic, but if they had been in place, the embezzlement and the magnitude of it would not have happened.

If management focuses on the fraud triangle and tries to eliminate the points of the triangle, the risk of fraud should decrease. The company might consider an employee loan program in order to reduce pressure on employees who have hit hard times. An employee assistance program of this type, or something similar, would not only decrease the pressure on the employee, but it would alert management to any possible problems. The opportunity leg of the triangle could be handled by an increase in internal control; namely, segregation of duties. Management also needs to deal with the rationalization leg of the triangle and set a goal of not enabling employees to rationalize committing fraud on the company. Management, from the owner down, needs to have a specific ethics policy that all in the company must adhere to. The policy must encourage all employees to report possible wrongdoings and it must state that anyone caught committing fraud will be prosecuted. The company could consider an anonymous reporting system about any areas of concern.

The Sarbanes Oxley Act of 2002 applies to publicly held companies, but as the research of ACFE shows, fraud is much more prevalent in privately held companies. Sarbanes-Oxley focused on increasing and strengthening internal controls and corporate governance which are clearly applicable and appropriate in a privately held organization as well.

\section{AUTHOR INFORMATION}

Lynn Ruggieri is an Associate Professor of Accounting at Roger Williams University. Her educational background includes- J.D. Southern New England School of Law, Dartmouth MA, 2008, M.S.T. Bryant College, Smithfield RI, 1991, M.B.A. Providence College, Providence RI, 1991, B.S. Bryant College, Smithfield RI, 1984. Her professional interests in research include U.S. Conversion to International Reporting Standards, Fraud Examination, Case Studies, and Business Valuation. Her teaching interests include Advanced Accounting, Auditing, International Accounting, Managerial Accounting, Financial Accounting and Forensic Accounting. E-mail: 1ruggieri@rwu.edu

\section{REFERENCES}

1. $\quad$ Association of Fraud Examiners Inc., ed. "2006 Global Fraud Study.” Report to the Nations on Occupational Fraud and Abuse (2006).

2. Cohen, J., Ding Y., Lesage, C., Stolowy, H. (2010). Corporate fraud and managers behavior; Evidence from the press. Journal of Business Ethics, 95, 271-315.

3. $\quad$ Ernst \& Young, Fraud: The Unmanaged Risk; $8^{\text {th }}$ Global Survey, 2002.

4. J\&J Materials, retrieved from http://jimaterials.com/.

5. Marco, P (2006, September 23). Cumberland Woman Lived Large on Embezzled \$9 million. Providence Journal, p A3.

6. Rittenberg, L. Johnstone, K. \& Gramling, A. (2012) Auditing A Business Risk Approach. Mason OH; South-Western Cengage Learning.

7. U.S District Court of Massachusetts, United States of America v. Angela Buckborough Platt Defendant. Case 1:07-cr-10028.

8. Swidey, N. (2006, September 17). The Inside Job; The Boss Thought she was the Hardest Working Person on his Payroll, Maybe She was, It's not so Easy Building And Hiding An Extravagant, Second Life with Company Money But How Could A Scam This Big Go Unnoticed for So Long? The Boston Globe, 1-4.

9. Wells, J. (2011) Principles of Fraud Examination. New Jersey, John Wiley \& Sons. 


\section{NOTES}

